\title{
21st Century Skills: Literacy-Based Learning in Academic Debate Classes for University Students
}

\author{
Sueb \\ Universitas Negeri Surabaya \\ Surabaya, Indonesia \\ sueb@unesa.ac.id
}

\author{
Lina Purwaning Hartanti \\ Universitas Negeri Surabaya \\ Surabaya, Indonesia
}

\author{
Layli Hidayah \\ Universitas Islam Malang \\ Malang, Indonesia
}

\begin{abstract}
In today's economic-driven community, the trend of education is to prepare the students more than social and numerical skills. The trend in the future requires more complex demands related to the students' skills, ranging from literacy and self-autonomy to collaboration ability with others to solve problems. This issue is closely related to the policy-making process in higher education which should concern with the integration of foundational literacies related to core skills in everyday life to the curriculum development, that each course should promote foundational literacies and relate the classroom activities to the application in the real world in the form of meaningful learning and authentic approaches. This case study was conducted to observe the debating practices in language classroom, particularly the action research for the implementation of literacy-based learning through integrated instructional strategies in speaking for academic debate class whether to certain extend it has prepared the students to the expected $21^{\text {st }}$ Century skills. Through classroom observation and reflective discussion, students demonstrate substantial progress both in communication competence in advocacy, the awareness of recent issues, and fulfill the required $21^{\text {st }}$ Century skills.
\end{abstract}

Keywords-literacy-based learning, instructional strategies, debate class, 21-century skills

\section{INTRODUCTION}

To thrive more in the $21^{\text {st }}$ Century, students need more than academic skills like language and arts and science, technology, engineering, and mathematics (STEM) - what students need, however, is beyond such technical and practical skills such as critical thinking, literacy ability, problemsolving, persistence, ability to collaborate and sense of curiosity, which are categorized as the $21^{\text {st }}$ Century skills. These skills become emerging trend in the current education and the students should be accommodated through proper instructional strategies supported with well-planned curriculum and policy in order to meet the skills they expect to succeed in the future. This study describes how the utilization of literacy-based into language learning might become one effort to learn target language as well as prepare students to master the $21^{\text {st }}$ century skills

In Indonesian context, the trend even becomes more challenging in relation to the students' low literacy level on mathematics, science, and reading as well as problem-solving ability. According to the results of OECD Program of International Students Assessment (PISA) in 2015, despite the fact Indonesia has shown an increase since 2012, it is statistically unchanged [1]. In this program, Indonesia has been standing in lowermost ranks among the participating countries. The ranks in these editions have become the tipping point for Indonesian authority to resolve the issues by thriving literacy movement through its policies through Minister of Education and Culture. The policy instills the principles of literacy in the curriculum as well as has included strengthening teacher subject matter competencies through stronger quality control at teacher training colleges and through high quality continuous professional development.

Along with the implementation of literacy-based values in education sector in Indonesia, the demand of 21-century skills is getting more complex and the reality in the society statistically low in terms of literacy and numeracy; thus, there should be commitment from relevant stakeholders to create radical changes through policies and practices. In other words, underlying the skills gaps are significant that might impede learning, this becomes the indication that many students might not experience the education as they need and expect to prosper in $21^{\text {st }}$ Century; in turn, the country is not finding enough human skilled resources to compete in the future.

Relevant stakeholders should realign the policy and practices in education sector in order to facilitate the students to be ready in economic-driven community in $21^{\text {st }}$ century. According to World Economic Forum [2] through metaanalysis of research in 24 countries, there are sixteen skills 
required in $21^{\text {st }}$ century, clustered into three broad categories, namely 1) foundational literacy which represents how students apply core skills to everyday tasks, including literacy, numeracy, scientific literacy, IT literacy, financial literacy, and cultural and civic cultural literacy; 2) competencies which describe how students approach complex challenges, e.g. critical thinking and problem-solving skills, creativity, communication, and collaboration; and 3) character qualities that drive the students to approach the changing environment, e.g. curiosity, initiative, persistence, adaptability, leadership, and social and cultural awareness.

While the policy-makers are focusing on foundational literacy with more relevant indicators embedding the $21^{\text {st }}$ Century skills, other stakeholders such as language instructors may develop the curriculum to accommodate the $21^{\text {st }}$ century skills among students through literacy-based instructional strategies in language classroom. The utilization of literacy in language classroom in Indonesia, or Asian countries in wider context, has been limited despite showing progress. One of the reasons, the lack of critical literacy in EFL context might be due to foreign language instructors who underestimate the capability of their learners to have a critical attitude using a variety of texts to nurture social justice [3]. This belief might contradict government's commitment to promote literacy through education as well as future plan to prepare younger generation to prosper in $21^{\text {st }}$ Century.

This condition should become a momentum for stakeholders in the area of foreign language education to integrate the use of literacy-based learning, namely introducing the four dimensions of critical literacy in classroom discussion [4], e.g. speaking for debate class. This study is aimed at elaborating the implementation of literacybased learning in academic debate classroom as part of the education praxis in $21^{\text {st }}$ century for the students' preparedness upon the sixteen skills required in $21^{\text {st }}$ Century.

\section{METHOD}

\section{A. Participants}

This is a case study by nature conducted at the Speaking III classes (speaking for critical context in the form of academic debate). The study involved university students ( $n=42)$ majoring on English Language Teaching (ELT) study program at one state university in East Java. The students were typically believed to have minimum or absent experience in debating community, debate-related activities, or any debating championships. Researchers had full access to the classes as the research subjects to which could adapt the curriculum as well as the teaching materials, including the instructional strategies by still considering the set curriculum by the Department. Additionally, the students involved in this study had low reading habit as it was indicated from the preliminary studies investigating the same students in the early semester by referring to the academic record (during academic supervision), showing on the average number of books having been read amounted to 1.3 books in one academic semester, and the students set on the academic contract for the upcoming semester which was in average of 1.7 books in one semester. This condition was believed to have affected to the students' low performance during the first speech performance in the debate class where the students were only able to speak on average of 3 minutes and 26 seconds (3'26") of the expected 7'20" substantive speech in the learning outcomes based on course syllabus. Moreover, students' analyses during the speech were not contextualized and lacked use of supporting data and relevant evidence in their arguments. As the results, the students were considered fail to give bold and relevant resolution upon the issues being debated.

\section{B. Procedures}

This study was conducted in the whole semester in two parallel classes through the same treatment, which was literacy-based integrated-skill instructional strategies in the speaking for academic debate class; the integrated-skill strategy is quite different compared with the other language skill classes which are taught discretely. The integrated approach in the language skills is believed to increase the effectiveness of language competence and communication skills of the students [5] [6], by involving reading and writing as well as listening activities in the speaking for debate classes.

The instructional strategies employed in the speaking for debate class required the students not only to perform their argumentative speech, rather required reading list that should be comprehended, and written report should be submitted after the debate performance in the classroom. The rationale to the employment of the literacy-based learning is to answer the issues of low critical thinking and problem solving in the debating activities due to lack of reading and supporting evidence in students' performance during the preliminary studies. In addition, the literacy-based instructional strategy was employed collaboratively during the in-class debate activities where students were paired with their friends (debate partners/teammates) and small groups functioning as debate teams. The topics (motions in debate) in the classrooms were chosen upon the classroom agreement by considering relevant and debatable topics to be resolved, ranging from education, social economics, health, environment, and politics.

\section{FINDINGS AND DISCUSSION}

This section discusses three main findings of the study concerning with the reading exposure in relation with students' autonomous behavior in comprehending the reading materials for debate performance, how the reading exposure affects the students' debate performance, and the last aspect is how this would be in line with the $21^{\text {st }}$ century skills.

\section{A. Reading Exposures and Student's Autonomous Behavior}

This section discusses the general idea upon the implementation of literacy-based instructional strategies by increasing reading sources exposure in debating class. It has 
impacts on students' debating performance, which includes improved matter and debating content along with the critical analyses towards the issues being resolved, and at the end students show better structure of their argumentation. For each motion, students were encouraged to utilize relevant sources as to build their understanding and gain supporting evidences in constructing the arguments. Throughout the semester, there were six motions which had been agreed to be debated in the classes, and at least five days before the next meeting they were given to the students in order to give opportunity for the students to research the data and relevant sources, namely news articles both national news features (NN) and international news (IN), (academic) journals or publication ( $\mathrm{J}$ ), discussion forum $(\mathrm{F})$, and blogs $(\mathrm{B})$.

TABLE I. READING SOURCES EXPOSURE

\begin{tabular}{|l|c|c|c|l|}
\hline \multicolumn{1}{|c|}{ Motions } & $\begin{array}{c}\text { Number } \\
\text { of } \\
\text { readings } \\
\text { /class }\end{array}$ & Sources & $\begin{array}{c}\text { Average } \\
\text { reading } \\
\text { /student }\end{array}$ & \multicolumn{1}{|c|}{$\begin{array}{c}\text { Information and } \\
\text { classroom reflection }\end{array}$} \\
\hline Education & - & NN, B & 2 & $\begin{array}{l}\text { Not given clear } \\
\text { instruction on } \\
\text { reading lists }\end{array}$ \\
\hline Politic & 12 & NN, IN & 4 & $\begin{array}{l}\text { Harder as it is new, } \\
\text { beyond their major }\end{array}$ \\
\hline Media & 14 & $\begin{array}{c}\text { NN, IN, } \\
\text { J, F }\end{array}$ & 4 & $\begin{array}{l}\text { Robust data, } \\
\text { contextualized } \\
\text { debate }\end{array}$ \\
\hline Health & 22 & 6 & $\begin{array}{l}\text { Half of students } \\
\text { defined } \\
\text { ambiguously, local } \\
\text { issues as examples }\end{array}$ \\
\hline Economy & 33 & $\begin{array}{c}\text { NN, IN, } \\
\text { J, F }\end{array}$ & 6 & $\begin{array}{l}\text { Fluent and } \\
\text { confident }\end{array}$ \\
\hline Environment & 24 & $\begin{array}{l}\text { Harder as it was } \\
\text { complex issue }\end{array}$ \\
\hline
\end{tabular}

Throughout the semester, students' reading habits showed positive trend; the students included more reading sources and genres to support their argumentation. Most of the readings were taken from news articles, both national and international news. Students were given five days to share links in an online forum through social media application platform as well as give comments on the links which have been shared by their friends. To this stage, students have experienced foundational literacy, particularly in the aspect of introducing the autonomous behavior of reading and writing.

Reading habits should be preferably beyond the classroom, particularly when the classroom hour is limited [9]. One solution was through literacy-based learning where students were encouraged to analyze the issues of each motion being debated and map relevant sources that they may need for the debate in the next session. The students were provided with structured task instruction on the context, how to analyze the issues, find relevant materials, and how to extend their reading lists as supporting data. The instruction employed by the instructor was also to focus on the possible use of multiple perspectives as part of the critical literacy to enrich the analyses, particularly from the view point of marginalized parties [4]. Such structured instruction on expanding their reading exposure to prepare for debating is reasonable in the curriculum for higher education (see National Standard of Higher Education) [10], that students should at least experience classical learning, structured assignment, and group discussion for each credit they take in the university.

With the current instructional strategies that include literacy-based learning, the definition of literacy which is not only the capability of a person to be able to read and write, but also a powerful means to organize, expand, and provide resources and information that can be used to change our social efforts [11] can be experienced by the students of the speaking for debate classes. Thus, the students experienced some benefits from the expanded reading exposure, namely 1) the students are able to deliver better analyses to the issues in the motion, such as why such motion appears and what stance should be taken; 2) the students are able to map clearer issues in order to give solution and advocate for the solution; and 3) the students work collaboratively with their peers to solve the problem through shared sources, particularly when the students were put into smaller team/group.

\section{B. Student's Performance in Debate Class}

In order to assess students' performance in the debate class, there are three main indicators employed by Indonesian debating community, namely 1) matter which deals with content, logical analysis, and relevance of the data, 2) method which manages the students to use good structure delivery including share the speaker's role during the debate, and 3) manner which deals with students' gesture, delivery, and style.

TABLE II. The Average Score of Students' Performance

\begin{tabular}{|c|c|c|c|c|c|c|c|c|}
\hline & \multirow{2}{*}{ Aspects } & \multicolumn{6}{|c|}{ Motions } & \multirow{2}{*}{ Information } \\
\hline & & 1 & 2 & 3 & 4 & 5 & 6 & \\
\hline \multirow{3}{*}{$\begin{array}{l}\text { Average } \\
\text { Score }\end{array}$} & Matter & 75 & 62 & 84 & 81 & $85 *$ & 82 & $\begin{array}{l}\text { Students } \\
\text { brought at } \\
\text { least } 2 \\
\text { arguments } \\
\text { in one } \\
\text { speech }\end{array}$ \\
\hline & Method & 72 & 72 & 85 & 85 & 85 & 84 & $\begin{array}{l}\text { Individual } \\
\text { and team- } \\
\text { based } \\
\text { method }\end{array}$ \\
\hline & Manner & 75 & 67 & 80 & 84 & 84 & 85 & $\begin{array}{l}\text { Gesture } \\
\text { and } \\
\text { language } \\
\text { use }\end{array}$ \\
\hline
\end{tabular}

*85 is considered as the averaged score for professional debaters (in debating championships)

Despite it is hard to determine the indicators for competencies and character qualities, debating activities have had already the standard adjudication observing the student's analytical and problem-solving ability during the debate.

According to the tabulation, students' performance showed positive trend in the three area of debating skills from motions 1 to 6 . In terms of analytical and problem solving ability, the students are able to content deliver complete argumentation, with at least two arguments for each speaker. The arguments brought by the students during the debate consisted of four main elements: assertion, logical reasoning and analyses, relevant evidence, and conclusion to the main topic of the 
debate. In terms of logical reasoning and relevant evidence, this was clear how the students' reading exposure gives positive impacts in the form of factual issues. Students brought contextualized issues, theoretical bases, and also statistics to support their argument.

During reflection at the end of the class, students were invited to share their experience regarding the strategy sharing reading sources publicly on social media platform (group members) which was helpful as to give sources with specific theme. In addition, students felt that as long as the topic was familiar with their life (e.g. motion 1 about education); they considered not preparing significant sources. As the result, even though they are education major yet with minimum reading sources, students experienced difficulties in building the cases and speech delivery due to lack of understanding upon the issues and minimum supporting data.

Other indicators showing positive trend according to students' performance are as follows:

- Student's engagement. Students were observed to be actively engaged with their peers and work collaboratively with other students during classroom activities, particularly during case-building session, distributing speaker's roles during debate, and solving different point of view with their counterparts during brainstorming, case-building, and during debates. For the last finding, such attitudes indicate students have tolerance and adaptability to resolve with other teams, which are obviously having different stance with their team.

- Initiative and curiosity. These indicators were not directly observed during the classroom, only when some students were encouraged to give some questions in every analysis after the debating exhibitions. Instead, these indicators are closely related with autonomous behavior, that debaters have to know what their need for debating and how to gain the information upon the target. Debating practices cover most of the cognitive principles of language pedagogy. The role of autonomous learning might help the learners to be more knowledgeable beyond the classroom as well as have wider registers and intercultural knowledge; content, language skills, and intercultural knowledge become essential aspects that might increase language skills [12].

\section{Reflection on Integrated Instructional Strategies}

In this section, it is important to reflect whether the implementation of literacy-based learning in debate class has impact on the students' preparedness to compete in $21^{\text {st }}$ Century. The reflection was also intended to observe students' feedback regarding learning experience upon the implementation of the instructional strategies; whether the instructional strategies have met their needs in $21^{\text {st }}$ Century. In general, students felt that the literacy-based and integrated instructional strategies have positive impact on the learning behavior, particularly students' autonomous habits which in turn will improve their academic performance.
In addition, in order to measure whether the instructional strategies have met the students' needs as part of the trend of education in $21^{\text {st }}$ Century. The results, 11 of 16 skills required in $21^{\text {st }}$ Century as asserted by World Economic Forum (2015) [2] are accommodated through the implementation of literacybased learning in debate classes. Detail reflection is presented in the as follows:

TABLE III. REFLECTION OF LITERACY-BASED LEARNING IN DEBATE CLASS ON SKILLS REQUIRED IN $21^{\text {ST }}$ CENTURY

\begin{tabular}{|c|c|c|c|}
\hline Criteria & Skills* & $\begin{array}{c}\text { Acco- } \\
\text { mmodate } \\
\text { Yes/No }\end{array}$ & $\begin{array}{l}\text { Information and } \\
\text { classroom reflection }\end{array}$ \\
\hline \multirow{5}{*}{$\begin{array}{l}\text { Foundational } \\
\text { Literacy }\end{array}$} & Literacy & Yes & \multirow{5}{*}{$\begin{array}{l}\text { Students have been } \\
\text { exposed with lots } \\
\text { of reading even } \\
\text { beyond their major. } \\
\text { Students utilized } \\
\text { IT to research the } \\
\text { matter with varied } \\
\text { perspectives. }\end{array}$} \\
\hline & Numeracy & No & \\
\hline & ICT literacy & Yes & \\
\hline & $\begin{array}{l}\text { Financial } \\
\text { literacy }\end{array}$ & No & \\
\hline & $\begin{array}{l}\text { Cultural and } \\
\text { civic literacy }\end{array}$ & Yes & \\
\hline \multirow{4}{*}{ Competencies } & $\begin{array}{l}\text { Critical } \\
\text { thinking / } \\
\text { problem- } \\
\text { solving }\end{array}$ & Yes & \multirow{4}{*}{$\begin{array}{l}\text { It might be the } \\
\text { most significant } \\
\text { skills being } \\
\text { accommodated in } \\
\text { debating activities. } \\
\text { In addition, } \\
\text { students are able to } \\
\text { advocate idea } \\
\text { eloquently and } \\
\text { collaboratively }\end{array}$} \\
\hline & Creativity & Yes & \\
\hline & Communication & Yes & \\
\hline & Collaboration & Yes & \\
\hline \multirow{6}{*}{$\begin{array}{l}\text { Character } \\
\text { Quality }\end{array}$} & Curiosity & Yes & \multirow{6}{*}{$\begin{array}{l}\text { Two main skills: } \\
\text { how debating } \\
\text { empowers } \\
\text { students' } \\
\text { autonomous } \\
\text { learning behavior } \\
\text { and how it } \\
\text { increases social } \\
\text { awareness due to } \\
\text { knowledge from } \\
\text { several } \\
\text { perspectives. }\end{array}$} \\
\hline & Initiative & Yes & \\
\hline & Persistence & No & \\
\hline & Adaptability & Yes & \\
\hline & Leadership & No & \\
\hline & $\begin{array}{l}\text { Social \& } \\
\text { cultural } \\
\text { awareness }\end{array}$ & Yes & \\
\hline
\end{tabular}

*Sixteen skills required in $21^{\text {st }}$ Century as proposed by World Economic Forum (2015) [2]

In relation to the stakeholder's commitment to increase the literacy and numeracy level, both international stakeholders like United Nations (through Education for All, UN Literacy Decade, Millennium Development Goals, Sustainable Development Goals, etc.) and country-based policies, can be observed as the rhetoric instead of real significant action [7]. Take the policy by Indonesian Government through Minister of Education Culture has released Ministerial Regulation Number 23 of 2015 on Character Building, which includes school literacy movement, focuses only in primary and secondary school levels, e.g. 15-minute daily reading before the classes begin [8]. Despite the fact that the literacy movement involves teacher and parental guidance, the family and community literacy has yet to run due to low understanding of family and community upon literacy movement. This might be reasonable as the movement has been promoted within the last two years, yet such initiative of post-literacy for adult literacy is absent. Thus, the literacy culture has apparently been conducted in school context only, 
not including adult literacy. These are the drawbacks of government's commitment to promote literacy among citizens.

Corroborated through the reflection on how the skills required in $21^{\text {st }}$ Century can be accommodated through the implementation of literacy-based learning in debate class, this might suggest to the rhetorical campaign on literacy movement; that even simple modification of curriculum could accommodate literacy skills and other skills required in $21^{\text {st }}$ century. Moreover, students are expected to enhance their literacy culture gaining preferable information; it is believed students are encouraged to expand their knowledge as they have had already autonomous behavior as it was given through structured task in debate class.

\section{CONCLUSION}

The issues of lower rank of literacy skills in Indonesiaand other developing countries - seem paradoxical amid vast campaign on literacy, that the campaign has been rather rhetoric than action. This has led to the skills gap in today's economic-driven community. The implementation of literacybased learning in debate classroom by simple modification on the instructional strategies has shown to improve students' communication competence as part of the EFL learning, accommodate the skills required in $21^{\text {st }}$ century, and fulfill students' needs of proper learning to prosper in the future. With these instructional patterns, it is believed the debate class is imperative be applied in other setting as this is in line with the education paradigm in $21^{\text {st }}$ century. Standardization to the indicators and government's initiative to realign the policy require further study to enrich the literacy studies in different context as the medium to empower society in $21^{\text {st }}$ century.

\section{REFERENCES}

[1] World Bank. (2016). Indonesia - Program for International Student Assessment 2015. PISA education brief. Washington, D.C. : World Bank Group.

[2] World Economic Forum. (2015). New Vision for Education: Unlocking the Potential of Technology.

[3] Falkenstein, A. T. (2003). Critical literacy in an EFL (English as a Foreign Language) context. Doctor of Philosophy, Indiana University, Indiana.

[4] Lewison, M., Leland, C., \& Harste, J. C. (2008). Creating critical classrooms: $K-8$ reading and writing with an edge. New York: Lawrence Erlbaum Associates.

[5] Schnase, J. L., \& Cunnius, E. L. (Eds.). (1995). Proceedings from CSCL '95: The First International Conference on Computer Support for Collaborative Learning. Mahwah, NJ: Erlbaum

[6] Nunan, D. (2004). Task-based language teaching. Cambridge, England: Cambridge University Press. Retrieved from

[7] Robinson, C. (2005). Promoting Literacy: What is the Record of Education for All? International Journal of Education Development 25 (2005), pp. 436-444.

[8] Ministry of Education and Culture of Republic of Indonesia. Ministerial Regulation Number 23 of 2015 on Character Building.

[9] Richards, J.C. \& Schmidt, R. (2002). Longman Dictionary of Language Teaching and Applied Linguistics (3rd Ed.). Harlow: Pearson Education Limited.

[10] Ministry of Research, Technology, and Higher Education of Republic of Indonesia. Ministerial Regulation Number 44 of 2015 on National Standard of Higher Education.

[11] Bazerman, C. (2000). A Rhetoric for Literate Society: The tension between expanding practices and restricted theories. In M. Goggin (Ed.), Inventing a Discipline, Rhetoric and Composition in Action. NCTE: pp. 5-28.

[12] Brumfit, C., Florence, M. Mitchell, R. Johnston, B. \& Ford, P. (2005). Language Study in Higher Education and the Development of Criticality. International Journal of Applied Linguistics Vol. 15 No. 2 2005, pp. 145-168. 